\title{
Compartmentation of the Metabolism of Lactose, Galactose and Glucose in Escherichia coli
}

\author{
By D. C. H. McBRIEN* AND V. MOSES \\ Laboratory of Chemical Biodynamics and Lawrence Radiation Laboratory, \\ University of California, Berkeley, California, U.S.A. 94720
}

(Accepted for publication 14 August 1967)

\begin{abstract}
SUMMARY
Compartmentation phenomena were studied in the course of the simultaneous metabolism of glucose, galactose and lactose by organisms of Escherichia coli which were induced for either the lac operon, the gal operon, both, or neither. Metabolic patterns were investigated in each phenotype by incubating parallel identical cultures with the three sugars in equal chemical concentration but labelled differently with ${ }^{14} \mathrm{C}$. The four labelled substrates were glucose, galactose and lactose labelled either exclusively in the glucose moiety or exclusively in the galactose moiety.

The metabolites from free glucose in the medium equilibrated with those from free galactose in the medium, but did not equilibrate with metabolic products derived from glucose generated endogenously by the hydrolysis of lactose. Similarly, metabolic products derived from galactose formed in the hydrolysis of lactose equilibrated with those from glucose from the same source, but not with metabolic intermediates formed from either free glucose or free galactose in the medium. Other interpretations of these results, not involving metabolic compartmentation, have been considered and found inadequate to account for the observed results. Some of the implications of compartmentation in bacteria are discussed.
\end{abstract}

\section{INTRODUCTION}

Subcellular compartmentation of pools of metabolic intermediates is known to be a widespread phenomenon (Moses, 1966), and it is probable that compartmentation plays a role in the control of biochemical reactions in vivo. Most evidence for metabolic compartmentation so far obtained has come from studies on cells which contain observable barriers to the free diffusion of solutes. The present communication describes an investigation made upon an organism which contains no visible internal membranes, namely, Escherichia coli.

Compartmentation is not necessarily a morphological phenomenon; the free diffusion of metabolic intermediates may be inhibited in other ways. At a molecular level, for example, one might envisage compounds bound to the surface of an integrated enzyme sequence, with intermediates along the pathway never being released to equilibrate with their respective pools. Similarly, if the position at which a particular compound is formed and released in the cell is sufficiently distant from the location of its intracellular pool it may undergo reaction before reaching the intracellular pool,

* Present address: Department of Biology, Brunel University, London, W. 3. Please address requests for reprints to Berkeley.

Vol. 5I. No. I was issued I I April 1968 
thus preventing the latter from achieving true equilibrium with the compound at all its locations within the cell.

Experimentally, the study of compartmentation in living cells presents certain problems arising from the difficulty of distinguishing between several reservoirs of a substance without fractionating the cell and thereby causing its death. Those attempts which have been made to investigate compartmentation in vivo have relied upon studies of the metabolic behaviour of certain compounds. In some investigations metabolic data is best interpreted by supposing that certain substances exist in two or more nonequilibrating reservoirs. Moses \& Lonberg-Holm (I966) extended this approach and sought to expose metabolic compartmentation by designing experiments in which certain metabolites would be generated intracellularly in a number of ways, and would be recognizable as a result of radioactive labelling. This method has been used in the present study.

The area of metabolism chosen for study was that involving the hydrolysis of lactose to glucose and galactose, the subsequent phosphorylation of the monosaccharides, the isomerization of galactose derivatives to glucose derivatives, and the further metabolism of the latter in the cell. Escherichia coli, when grown in appropriate media, is able to metabolize lactose, glucose and galactose. During lactose metabolism, the monosaccharides are presumably released within the bacterium, while metabolism of the monosaccharides supplied directly from the medium must involve also the entry of the substances into the bacterium either as free sugars or as derivatives. The question we sought to answer was this: is glucose (or galactose) produced inside the bacterium by the hydrolysis of lactose distinct metabolically from glucose (or galactose) presented to the outside of the bacterium? Or put slightly differently: is the metabolic fate of glucose (or galactose) in any way dependent on its origin?

The problem may be studied by using a radioactive labelling technique. When cells are supplied simultaneously with glucose, galactose and lactose as substrates one might study the fate of various substrates by parallel experiments differing only in the location of the radioactive marker. In the present study it was necessary to use four parallel reaction vessels, each identical chemically, and containing all three sugars. The labelling pattern was then varied so that the four flasks were supplied with labelled glucose, labelled galactose, lactose labelled in the glucose moiety and lactose labelled in the galactose moiety, respectively. It was then possible to study, for example, the fate of glucose derived by the hydrolysis of lactose in bacteria which were simultaneously metabolizing glucose from the medium, and to compare this with the fate of glucose from the medium in a parallel culture of bacteria with an identical history which were also metabolizing glucose derived from lactose. Similar comparisons were also made for galactose, and between glucose and galactose.

Some of the enzymes of lactose and galactose metabolism are inducible and their intracellular levels may be greatly altered by growth in the presence of the appropriate inducers. Glucose metabolism, on the other hand, appears to be phenotypically constitutive in Escherichia coli. We included in our studies a comparison of lactose, glucose and galactose metabolism in bacteria induced either for the lactose enzymes, or for the galactose enzymes, or both, or neither. 


\section{METHODS}

Organism and growth conditions. Escherichia coli strain CAVALLI (lac gal $^{+}$met $^{-}$thy $\left.^{-}\right)$ was obtained from Dr A. Simmonds (Dept of Molecular Biology, University of California, Berkeley, Calif., U.S.A.). Stock cultures were maintained on M63 minimal medium (Pardee \& Prestidge, I96I) supplemented with glycerol $(0.2 \%, \mathrm{w} / \mathrm{v})$ and specific growth factors. Bacteria were grown in liquid medium with stirring at $37^{\circ}$. Full induction of the lac operon was achieved by growing the bacteria for many generations in the presence of $0.5 \mathrm{~mm}$-isopropyl- $\beta$-D-thiogalactoside (IPTG). The gal operon was induced by growth in the presence of $5 \mathrm{~mm}-\mathrm{D}$-fucose. When IPTG and fucose are present together at these concentrations there is no appreciable interaction of either inducer upon the inductive effect of the other (McBrien \& Moses, 1966).

Labelled substrates. [G- $\left.{ }^{14} \mathrm{C}\right]-\mathrm{D}-\mathrm{Glucose}$ (I07 $\mu \mathrm{c}$. $/ \mu \mathrm{mole}$ ) was prepared by the method of Putman \& Hassid (I952). [G- $\left.{ }^{14} \mathrm{C}\right]-\mathrm{D}-$ Galactose (I $\left.43 \mu \mathrm{c} . / \mu \mathrm{mole}\right)$ was prepared according to Bean, Putman, Trucco \& Hassid (I953) with minor modifications. It was found necessary to illuminate the algae used for the photosynthetic incorporation of ${ }^{14} \mathrm{CO}_{2}$ into glycerol-galactoside at a much lower light intensity (I I,000 lux) than was previously recommended. Galactose was separated and purified in the manner described by Abraham \& Hassid (1957). We are grateful to Dr S. Abraham for assistance in isolating the galactose.

$\left[\left(\mathrm{G}-{ }^{14} \mathrm{C}\right)\right.$ glucose]Lactose was prepared with lactose synthetase isolated from unpasteurized cow's milk (kindly provided by Challenge Dairies, Berkeley, California, U.S.A.) by the method of Babad \& Hassid (I964). [(G- $\left.{ }^{14} \mathrm{C}\right)$ galactose]Lactose was synthesized with a tissue preparation from the mammary gland of a lactating rat (Bartley, Abraham \& Chaikoff, 1966). In the preparation of both forms of labelled lactose the labelled hexoses described above were used undiluted by unlabelled sugars, and the products which were isolated and purified by preparative paper chromatography were assumed to have the same specific radioactivities as the parent hexoses. A small sample of each of the labelled lactoses was used to determine the proportion of ${ }^{14} \mathrm{C}$ activity which had been incorporated into the desired moiety. The labelled lactose was hydrolysed with a crude preparation of $\beta$-galactosidase obtained from a lacconstitutive strain of Escherichia coli and the glucose and galactose produced were separated by paper chromatography in ethyl acetate + pyridine + acetic acid + water $(5+5+2+3$, by vol.). The sugars were located by radioautography, with known radioactive markers on guide strips, the spots excised and the radioactivity measured with opposed end-window Geiger-Müller tubes. In each case at least $97 \%$ of the activity was found in the desired moiety.

Labelling experiments. The experimental procedure was adapted from that described by Moses \& Lonberg-Holm (1966). Bacteria growing in exponential phase in glycerol minimal medium were harvested at a concentration equiv. $225 \mu \mathrm{g}$. bacterial protein $/ \mathrm{ml}$. Growth and protein synthesis were halted before harvesting by adding chloramphenicol (100 $\mu \mathrm{g}$. $/ \mathrm{ml}$.). The bacteria were washed and resuspended in $0.0 \mathrm{I} \mathrm{M-}$ phosphate buffer ( $\mathrm{pH} 7 \cdot \mathrm{I})$ containing chloramphenicol $(25 \mu \mathrm{g} . / \mathrm{ml}$.). To $20 \mathrm{ml}$. of this bacterial suspension was added $0.4 \mathrm{ml}$. of a solution containing $0.7 \%(\mathrm{w} / \mathrm{v})$ each of lactose, glucose and galactose: after mixing, this gave a concentration of $0.76 \mathrm{~mm}$ for the monosaccharides and $0.40 \mathrm{~mm}$ for lactose. Four samples of bacterial suspension, each of $2.0 \mathrm{ml}$., were transferred to $20 \mathrm{ml}$. flat-bottomed glass vials (as used for 
scintillation counting) and placed in a water bath at $37^{\circ}$. The contents of the vials were stirred vigorously by using small polythene-covered magnets over magnetic stirrer motors operating at maximum speed. Fifteen min. after adding the mixed sugars to the bacteria the labelled sugars were introduced as indicated in Table I. There was no significant contribution to the total sugar content by the addition of the labelled material.

During the following $45 \mathrm{~min}$. after adding the labelled sugars 15 samples of about $30 \mu$ l. each were withdrawn from each vial at known times. Each sample was mixed immediately with $0.4 \mathrm{ml}$. of ethanol $(90 \%, \mathrm{v} / \mathrm{v}$, in water) in pre-weighed stoppered tubes. The tubes were subsequently reweighed to determine the sample size actually

\section{Table I. Labelled substrates added to the four parallel vessels of each experiment}

Escherichia coli strain CAVALLI bacteria suspended in 0.01 M-phosphate buffer $(\mathrm{pH} 7 \cdot 1)$ containing chloramphenicol $(25 \mu \mathrm{g} . / \mathrm{ml}$.) received $0.76 \mathrm{~mm}$-glucose, $0.76 \mathrm{~mm}$-galactose and $0.40 \mathrm{~mm}$-lactose. Four parallel portions of the suspension (each of $2 \mathrm{ml}$.) were incubated at $37^{\circ}$ with stirring. Fifteen min. later labelled sugars were added as indicated below.

\begin{tabular}{|c|c|c|c|c|}
\hline \multirow[b]{2}{*}{ Vessel } & \multirow[b]{2}{*}{ Substrate } & \multirow{2}{*}{$\begin{array}{l}\text { Vol. of } \\
\text { substrate } \\
\text { solution } \\
(\mu l .)\end{array}$} & \multicolumn{2}{|c|}{$\begin{array}{l}\text { Amount of labelled } \\
\text { substrate added }\end{array}$} \\
\hline & & & $\mu \mathrm{c}$. & $\mu$ moles \\
\hline A & {$\left[\mathrm{G}-{ }^{14} \mathrm{C}\right]$ Glucose } & 40 & $8 \cdot 04$ & 0.075 \\
\hline B & [G-14 C]Galactose & 40 & $6 \cdot 52$ & 0.046 \\
\hline C & {$\left[\left(G-{ }^{14} \mathrm{C}\right)\right.$ Glucose $]$ lactose } & 30 & $7 \cdot 08$ & 0.066 \\
\hline D & {$\left[\left(\mathrm{G}-{ }^{14} \mathrm{C}\right)\right.$ Galactose]lactose } & 40 & $7 \cdot 80$ & 0.055 \\
\hline
\end{tabular}

taken. The contents of each tube were chromatographed in toto by two-dimensional paper chromatography on Ederol no. 202 paper (J. C. Binzer G.m.b.H., Hatzfeld/ Eder, Germany). The solvents were: in the first dimension 90\% phenol+water + glacial acetic acid $+0.5 \mathrm{M}-\mathrm{K}_{2}$ EDTA $(420+80+5+\mathrm{r}$, by vol.), and in the second dimension butan-I-ol + propionic acid + water $(20+9+\mathrm{II}$, by vol.). Radioactive materials on the chromatograms were located by radioautography, and spots so located were excised and counted by using the automatic apparatus described by Moses \& Lonberg-Holm (1963). Spots selected for identification were eluted and cochromatographed with known unlabelled markers. Dicarboxylic acids were located by using bromocresol green reagent (Lugg \& Overell, 1948), amino acids with ninhydrin and sugars with $\mathrm{AgNO}_{3}$ (Smith, 1960).

The experiment was done four times with bacteria in different states of induction for the lac and gal operons. In bacteria in which neither of these operons were induced the amount of radioactivity incorporated into products from labelled galactose or labelled lactose was so small that no useful information could be obtained. This experiment is therefore not further discussed. The arrangements for the other three experiments are noted in Table 2.

\section{RESULTS}

The amount of utilization of the labelled substrates during the period of $45 \mathrm{~min}$. after their addition to the cells is shown in Table 3. It can be seen that in bacteria in which the lactose operon was induced lactose was rapidly hydrolysed to hexose, a large proportion of which accumulated, presumably because subsequent steps in its metabolism were rate limiting. In Table 3 the residual hexose formed from labelled lactose is counted as unused substrate. 


\section{Table 2. Phenotypes of the bacteria used in the labelling experiments}

Escherichia coli strain CAVALLI bacteria were grown in glycerol minimal medium with or without IPTG $(0.5 \mathrm{~mm})$ to induce the lactose enzymes or D-fucose $(5 \mathrm{~mm})$ to induce the galactose enzymes. The bacteria in exponential growth received chloramphenicol $(100 \mu \mathrm{g} . / \mathrm{ml}$.) immediately before harvesting and were then washed and resuspended in 0.01 M-phosphate

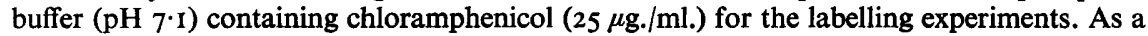
result of the presence of chloramphenicol no enzyme induction could take place during the subsequent metabolism with a mixture of glucose, galactose and lactose. Two ml. of bacterial suspension were used in each reaction vessel.

$\begin{array}{cllc}\text { Experiment } & \text { lac } \text { operon } & \text { gal } \text { operon } & \begin{array}{c}\text { Cell concentra- } \\ \text { tion }(\mu \mathrm{g} . \text { bac- } \\ \text { terial protein/ } \\ \text { ml. })\end{array} \\ \text { I } & \text { Induced } & \text { Induced } & 198 \\ 2 & \text { Not induced } & \text { Induced } & 246 \\ 3 & \text { Induced } & \text { Not induced } & 244\end{array}$

\section{Table 3. Utilization of labelled substrates by Escherichia coli strain CAVALLI}

Bacteria of the phenotypes shown in Table 2 were allowed to metabolize a mixture of glucose, galactose and lactose in four parallel incubation vessels. Each vessel contained ${ }^{14} \mathrm{C}$ in a different substrate: in free glucose, free galactose, the glucose moiety of lactose or the galactose moiety of lactose. This table presents data on the hydrolysis of lactose and on the utilization of hexoses both from free sugars in the medium and from those produced by lactose hydrolysis, all after $45 \mathrm{~min}$. incubation at $37^{\circ}$.

Extent of lactose hydrolysis ( $\%$ of total)

Based on $\left[\left(\mathrm{G}-{ }^{14} \mathrm{C}\right)\right.$ glucose]lactose

Based on [(G-14 $\mathrm{C})$ galactose]lactose

Lactose remaining as free hexose (\% of total)

Based on $\left[\left(\mathrm{G}^{-14} \mathrm{C}\right)\right.$ glucose]lactose

Based on [(G-4 $\mathrm{C})$ galactose]lactose

\begin{tabular}{|c|c|c|}
\hline \multicolumn{3}{|c|}{ Phenotype* } \\
\hline $\mathrm{lac}^{+} \mathrm{gal}^{+}$ & $\mathrm{lac}^{-} \mathrm{gal}^{+}$ & $\mathrm{lac}^{+} \mathrm{gal}^{-}$ \\
\hline 98 & 9 & $8 \mathrm{I}$ \\
\hline 96 & 17 & 85 \\
\hline 87 & 2 & 19 \\
\hline 37 & 4 & 92 \\
\hline 0.214 & O. I I I & 0.842 \\
\hline $0.37 \mathrm{I}$ & $2 \cdot 175$ & 0.417 \\
\hline 0.585 & $2 \cdot 286$ & I 259 \\
\hline 0.996 & 0.203 & o \\
\hline $1 \cdot 078$ & 0.817 & 0.153 \\
\hline $2 \cdot 074$ & I $\cdot 020$ & 0.153 \\
\hline 2.659 & $3 \cdot 306$ & I 4 I 2 \\
\hline
\end{tabular}

Glucose from lactose metabolized ( $\mu$ moles $/ \mathrm{mg}$. bacterial protein)

Free glucose metabolized ( $\mu$ moles $/ \mathrm{mg}$. bacterial protein)

Total glucose metabolized ( $\mu$ moles $/ \mathrm{mg}$. bacterial protein)

Galactose from lactose metabolized ( $\mu$ moles/mg. bacterial protein)

Free galactose metabolized ( $\mu$ moles $/ \mathrm{mg}$. bacterial protein)

Total galactose metabolized ( $\mu$ moles $/ \mathrm{mg}$. bacterial protein)

Total hexose metabolized ( $\mu$ moles $/ \mathrm{mg}$. bacterial protein)

* + indicates enzymes induced; - indicates enzymes not induced. 
With both the lactose and galactose operons induced (Expt. I) about $78 \%$ of all the hexose used was galactose, $37 \%$ of the total being galactose derived from lactose. When the main source of galactose was curtailed (Expt. 2) by failing to induce the lactose operon, the total consumption of carbohydrate did not decrease, and indeed increased to some extent. The lack of galactose from lactose was entirely compensated by the additional metabolism of glucose from the medium; the metabolism of galactose from the medium did not increase. This suggests that the pathway leading into metabolism from galactose in the medium was saturated in both experiments by galactose

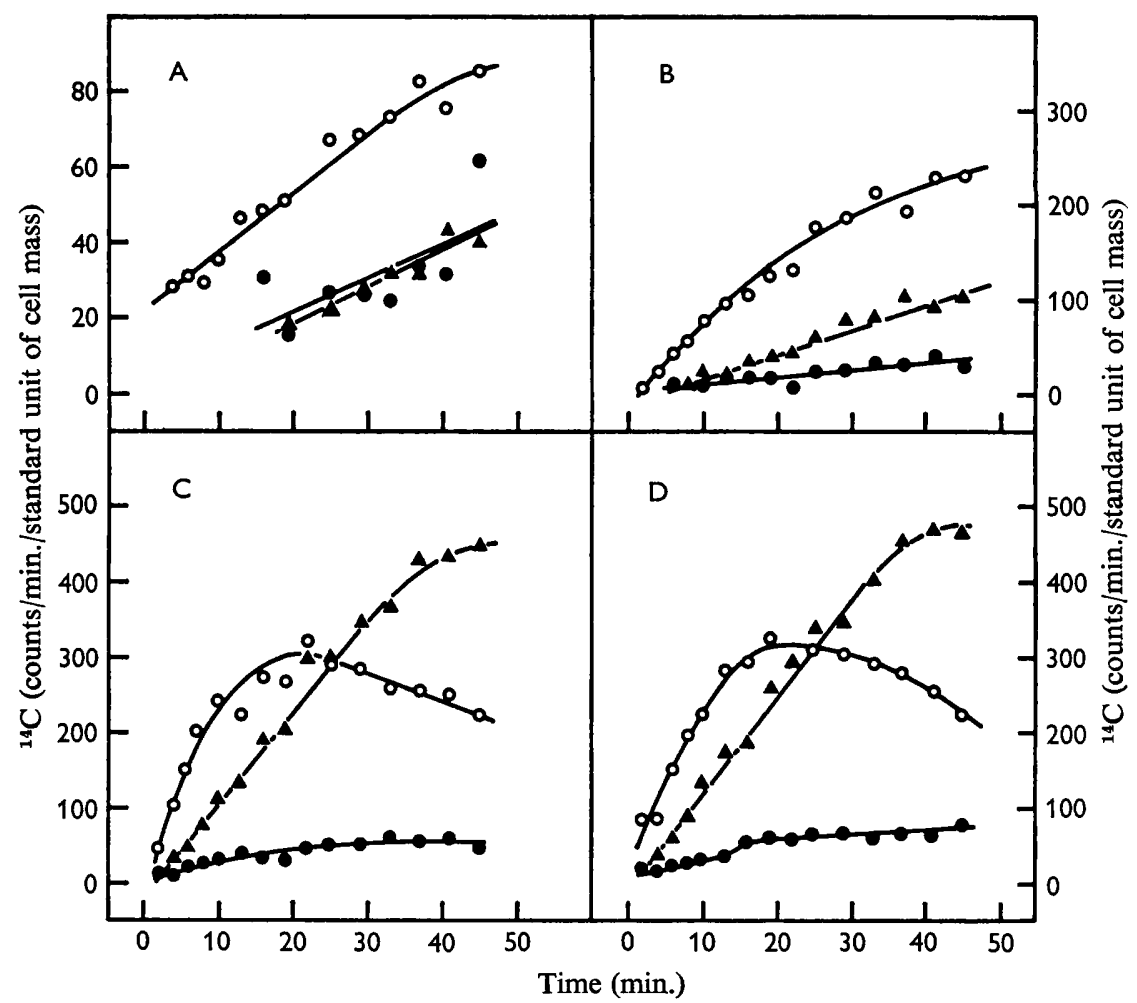

Fig. I. Formation of glutamate, citrate and succinate in Escherichia coli induced for both the lac and gal operons, and supplied with a mixture of glucose, galactose and lactose labelled in various ways. $A,\left[\mathrm{G}-{ }^{14} \mathrm{C}\right]$ glucose; $B,\left[\mathrm{G}-{ }^{14} \mathrm{C}\right]$ galactose; $C,\left[\left(\mathrm{G}-{ }^{14} \mathrm{C}\right)\right.$ glucose $]$ lactose; $D,\left[\left(\mathrm{G}^{-14} \mathrm{C}\right)\right.$ galactose $]$ lactose. $\mathrm{O}$, glutamate; $\bullet$, citrate; $\boldsymbol{\Delta}$, succinate.

from this source. The other pathway leading into metabolism from galactose derived from lactose was not accessible to galactose in the medium. However, at a later stage in metabolism, probably the second of these pathways could be entered by glucose from the medium, since the pathway was now largely unoccupied by metabolites from the galactose moiety of lactose. Glucose from the medium could not enter this pathway, however, when it was occupied by galactose metabolites.

This pathway from lactose-galactose was more readily accessible to the glucose moiety of lactose than to free glucose when it was not occupied by galactose metabolites. In Expt. 3 elimination of both galactose pathways by failure to induce the 
galactose operon resulted in the greater utilization of lactose-glucose, since this was now available, rather than glucose from the medium. Thus we may conclude that when all the relevant operons were induced the carbohydrate of choice was galactose derived from the hydrolysis of lactose. When it was available, glucose derived from lactose

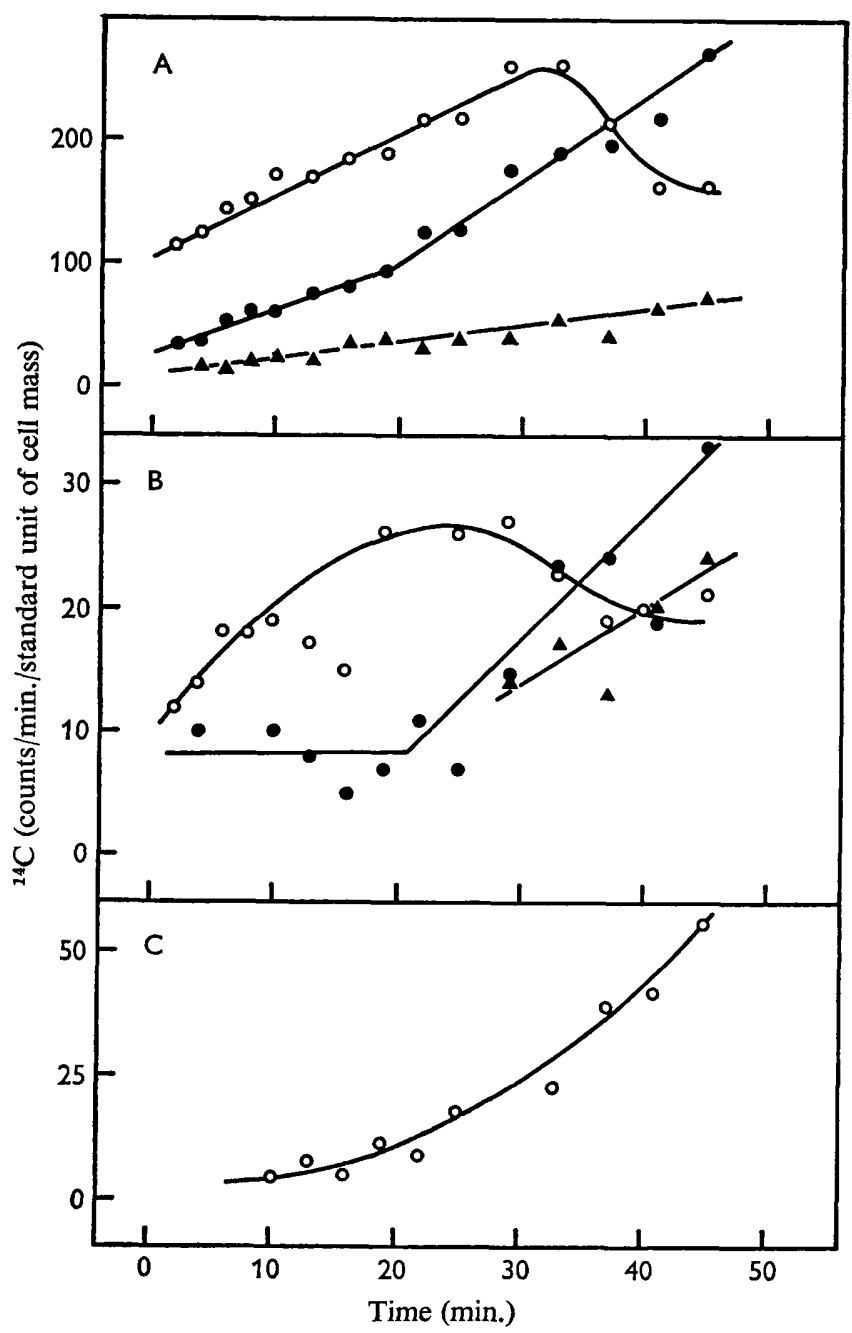

Fig. 2. Formation of glutamate, citrate and succinate in Escherichia coli induced for the gal operon only, and supplied with a mixture of glucose, galactose and lactose labelled in various ways. $A,\left[\mathrm{G}-{ }^{14} \mathrm{C}\right]$ glucose; $B,\left[\mathrm{G}^{-14} \mathrm{C}\right]$ galactose; $C,\left[\left(\mathrm{G}^{-14} \mathrm{C}\right)\right.$ glucose]lactose. No activity in these compounds was obtained with $\left[\left(\mathrm{G}^{-14} \mathrm{C}\right)\right.$ galactose]lactose. $\bigcirc$, glutamate;, citrate; $\Delta$, succinate.

was also used in preference to free glucose in the external environment, although the latter could be used when there was sufficient need. These considerations imply that the pools formed inside the organism from externally supplied and internally produced hexose do not mix to any large extent.

Inspection of the radioautographs of the chromatograms produced in these experi- 
ments prompted the selection for comparisons of the spots corresponding to citric, succinic and glutamic acids, because they were found on most of the chromatograms from each of the experiments and contained readily measurable ${ }^{14} \mathrm{C}$ activity. For the sake of simplicity data obtained from other spots, labelled to a smaller extent (with a

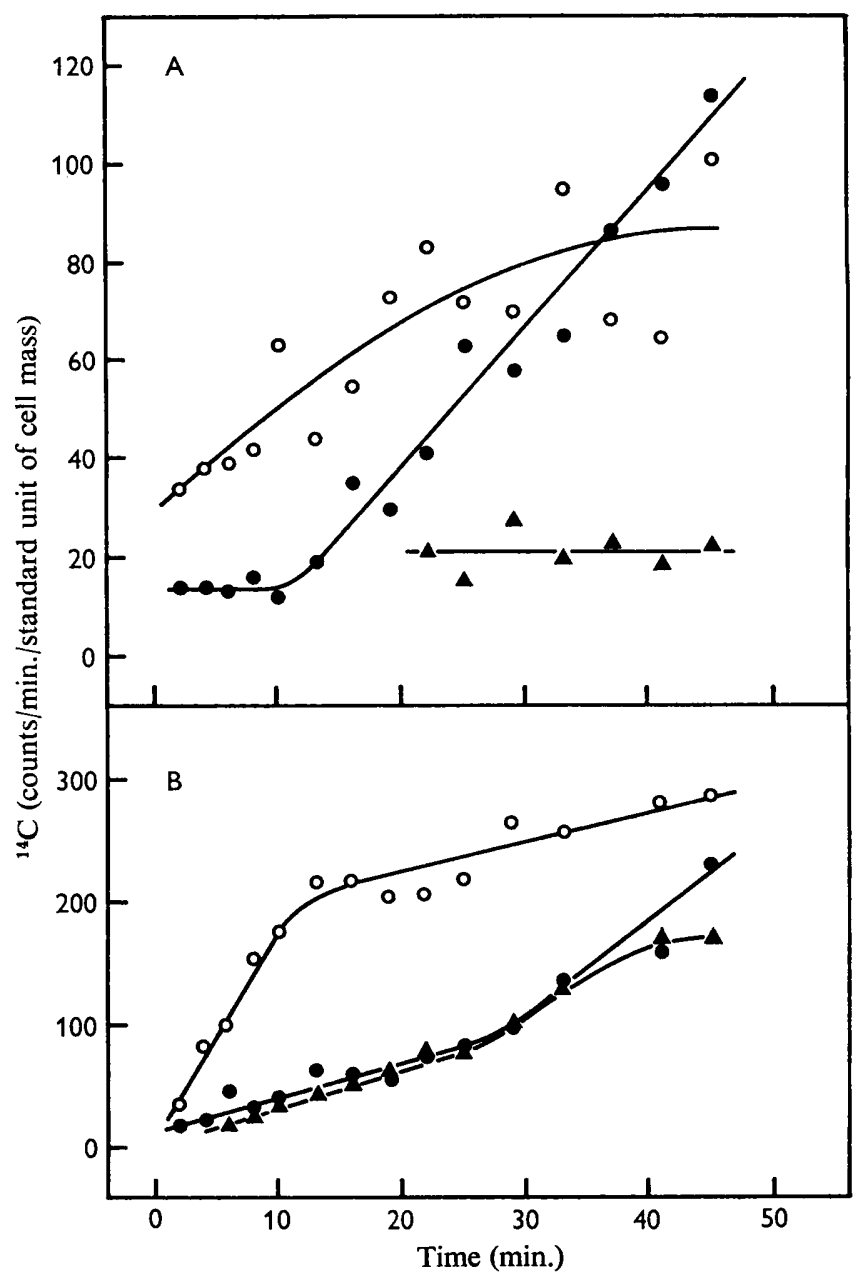

Fig. 3. Formation of glutamate, citrate and succinate in Escherichia coli induced for the lac operon only, and supplied with a mixture of glucose, galactose and lactose labelled in various ways. $A,\left[\mathrm{G}-{ }^{14} \mathrm{C}\right]$ glucose; $B,\left[\left(\mathrm{G}-{ }^{14} \mathrm{C}\right)\right.$ glucose $]$ lactose. No activity in these compounds was obtained with $\left[\mathrm{G}-{ }^{14} \mathrm{C}\right]$ galactose or $\left[\left(\mathrm{G}^{14} \mathrm{C}\right)\right.$ galactose]lactose. $O$, glutamate; $\boldsymbol{O}$, citrate; $\boldsymbol{\Lambda}$, succinate.

correspondingly greater scatter of results) and spots which were not subsequently identified will not be presented. Figures $\mathrm{I}-3$ show the activities of the three selected compounds from all the papers on which their activity was measurable. The results from a single, four-vessel, experiment are shown in each figure.

In considering the behaviour of various compounds shown in Figs. I-3 it should be borne in mind that quantitative comparisons between experiments performed on 
different days and with different batches of bacteria must always be made with caution. One is more confident in comparing parallel portions of the same culture since these certainly had a common history until a few minutes before the experiment began, and considerable effort was expended to maintain chemically identical conditions in each subculture after division of the parent stock.

Examination of Figs. I-3 shows that there were considerable differences between the relative pool sizes in different vessels of the same experiment. Before these can be discussed in detail one must be quite sure that they reflect aspects of metabolic organization and not merely trivial differences which might by chance have arisen among the four parallel vessels and which alone might account for the metabolic phenomena we observed. Within each experiment it is known that the bacteria and their chemical environment were the same in each vessel, differing only in the nature of the labelled substrate added. The only other possible variation we can conceive between the experimental conditions in each vessel is the degree of aeration. As stated earlier, aeration was achieved by using miniature magnetic stirrers made of stainless steel, sheathed in polythene, and rotated by stirrer motors with the rheostat speed control set at its maximum setting (I00 on the dial). The following experiment was designed to determine how critical the speed of stirring was for the rate of respiration of the bacteria.

Warburg flasks with no centre wells were each charged with $0.25 \mathrm{ml}$. of $20 \%$ (w/v) sodium hydroxide placed in'the side-arms. A suspension of bacteria in 0.0 I M-phosphate buffer ( $\mathrm{pH} 7 \cdot \mathrm{I}$ ) containing chloramphenicol $(25 \mu \mathrm{g} . / \mathrm{ml}$.) was prepared in exactly the same way as for the labelling experiments; the suspension contained equiv. $194 \mu \mathrm{g}$. bacterial protein $/ \mathrm{ml}$. The bacteria had been grown in the absence of inducers. The external diameter of the Warburg flasks was approximately $30 \mathrm{~mm}$. and of the vials used in the labelling experiments approximately $23 \mathrm{~mm}$. However, the latter were made of thinner glass and the difference between the internal diameters of the two vessels was probably less than between their external diameters.

Three samples $(2 \cdot 0, \mathrm{r} \cdot 0,0.5 \mathrm{ml}$.) of the bacterial suspension, each diluted to $2 \cdot 0 \mathrm{ml}$. with buffer, were placed in the cups of the Warburg flasks. The miniature magnetic stirrers were added, followed by $0.04 \mathrm{ml}$. of a solution containing $0.7 \%(\mathrm{w} / \mathrm{v})$ each of glucose, galactose and lactose. The flasks were attached to their manometers, immersed in a water bath at $37^{\circ}$ and stirring began with the rheostat speed controls set at 85-90 on the dial. This gave a speed somewhat less than that used in the labelling experiments when it was possible to operate the stirrers at maximum speed. After Io min. equilibration, measurements of oxygen consumption were begun. For the first $60 \mathrm{~min}$. the rates of oxygen consumption in each flask were constant, the values ( $\mu \mathrm{l} . \mathrm{O}_{2} / \mathrm{min} . / \mu \mathrm{g}$. bacterial protein) being $4 \cdot 38,4 \cdot 25$ and $4 \cdot 5 \mathrm{I}$ for flasks containing $2 \cdot 0 \mathrm{ml}$., $\mathrm{I} \cdot 0 \mathrm{ml}$. and $0.5 \mathrm{ml}$. of original bacterial suspension, respectively.

Since the rate of respiration was proportional to the volume of bacterial suspension used over a fourfold range, it must have been maximal. After incubation for $50 \mathrm{~min}$. the rate of stirring was decreased by turning the speed controls to 60 . The speed of stirring was not proportional to the potentiometer setting and it was observed that the stirrers appeared to slow down to much less than two-thirds of the original rate. As measured in the next $50 \mathrm{~min}$. the respiration rates were $\mathrm{I} \cdot 65,3.92$ and $2.89 \mu 1 . \mathrm{O}_{2} / \mathrm{min}$./ $\mu \mathrm{g}$. bacterial protein for the three flasks, respectively. The rate had thus decreased in three vessels to different extents. However, in the labelling experiments the stirrers were always operated at maximum speed. It must also be borne in mind that the total 
volume in each vessel during a labelling experiment decreased continuously as samples were withdrawn. It is therefore clear from these results that differences in aeration were not sufficient to account for the differences observed between the labelling patterns in different vessels.

\section{DISCUSSION}

If true steady-state conditions had been achieved in the labelling experiments each metabolic pool would gradually have been filled with ${ }^{14} \mathrm{C}$ until equilibrium with the outside solution was achieved; the activity would then have attained a constant maximum value. From Figs. I to 3 it can be seen that an approximation to these conditions was achieved in most cases. At the end of $45 \mathrm{~min}$. the rate of increase of radioactivity in each pool tended to decrease. In a few cases the degree of activity in the glutamate pool began to show a decrease after reaching a maximum value, and in some cases no plateau of activity was attained. However, the data presented in Fig. I indicate that the size of the succinic acid pool, through which passed the products of metabolism of the glucose and galactose derived from the hydrolysis of lactose, was much larger in comparison to the size of the pool of glutamate than that which received the products of metabolism of exogenous glucose and galactose. Figure 3 indicates that this same effect, although less pronounced, also held true for exogenous and endogenous glucose in bacteria which had a different complement of induced enzymes.

In addition to determinations of the relative sizes of pools, observations on the rates at which pools fill with activity may be helpful in determining whether more than one pool of each compound exists in the cells. For example, in Fig. I it can be seen that the pool of glutamate derived from either moiety of lactose began to decrease in activity about $20 \mathrm{~min}$. after the addition of label to the vessels, at which time the activity of the pool of glutamate derived from exogenous glucose or galactose was still increasing. Similarly, from Fig. 3 it will be seen that the size of the labelled pool of citric acid from external glucose became equal to, and subsequently greater than, the pool of labelled glutamate $36 \mathrm{~min}$. after the addition of the labelled material to the cells. However, the pool of labelled citrate derived from endogenously produced glucose did not exceed the size of the labelled glutamate pool within the period of the experiment. If all the labelled substrates are fed into a common pathway (there being only one pool of any intermediate in each cell) as shown in Fig. 4, then the pools of the three acids would behave identically in each vessel regardless of the nature of the labelled substrate. Since in any one of the labelling experiments the bacteria and their chemical environment were ostensibly identical, some explanation must be sought for the differences shown by the behaviour of the labelled pools depending on the identity of the substrate which was labelled.

Although metabolic compartmentation is able to account satisfactorily for the results of these experiments, two other possible interpretations must also be considered: lack of homogeneity in the bacterial population itself, and different environmental conditions in the several incubation vessels comprising each experiment.

The culture used in the present experiments was not synchronous, and it could be argued that bacteria in different stages of the growth cycle might have different enzyme complements (and thus might themselves act as separate compartments). There is considerable evidence that certain enzymes in Bacillus subtilis, Escherichia coli and yeast are produced discontinuously during the growth cycle of individual cells (Masters, 
Kuempel \& Pardee, 1964; Kuempel, Masters \& Pardee, 1965; Halvorson et al. 1964; Masters \& Donachie, 1966) although, taken as a whole, protein synthesis is a continuous process (Schaechter, Williamson, Hood \& Koch, 1962). The enzymes exhibiting discontinuous (or 'stepwise') synthesis are those whose synthesis is partially or wholly induced or de-repressed. Kuempel et al. (1965) proposed a model to explain this stepwise synthesis which involves a cyclic variation in the amount of repressor during one generation period. Halvorson et al. (1964) suggested a similar explanation.

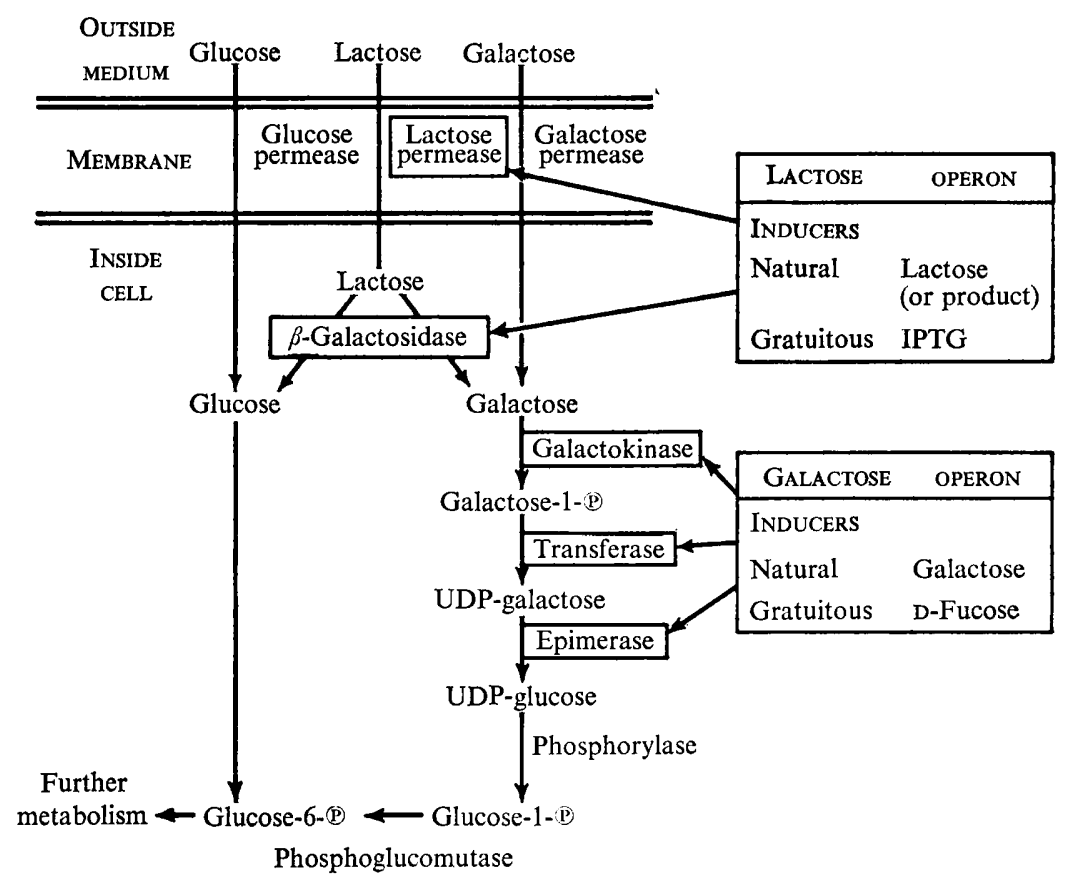

Fig. 4. Initial metabolic interrelations of lactose, galactose and glucose, showing inducible enzymes and some inducers.

They envisaged that transcription is switched on and off sequentially along the DNA molecule during the growth cycle. Thus, if inducers and repressors act by stimulating the rate of messenger RNA synthesis they must only function at given periods of the growth cycle. Halvorson et al. (1964) found that the addition of inducer to cells synthesizing enzyme under a repressed regime (e.g. at a basal rate) did not alter the timing of the induced stepwise synthesis of the enzyme. Evidence contrary to this view has been presented by Masters et al. (I964) and Masters \& Donachie (I966), who found that the synthesis of $\beta$-galactosidase under conditions of severe repression did not exhibit stepwise formation but was continuous at a rate which was proportional to the gene dosage (i.e. when the appropriate section of DNA was replicated the rate of synthesis also doubled).

No information is available about the timing of synthesis of enzymes on the central pathways of metabolism. Figure 4 shows the early stages in the metabolism of the sugars used in the present experiments. With the exception of those controlled by the added inducers the enzymes mediating the metabolism of these sugars are found in all normally functioning cells. These enzymes are probably subject to control mechanisms 
other than those which act solely at the genetic level, and the presence of any 'cytoplasmic' control over the enzymic activity of already synthesized protein would tend to counteract the in vivo effects of sudden increases in enzyme content caused by stepwise synthesis if this were to occur. For this reason, and because stepwise synthesis has never been demonstrated for these enzymes, it is not considered likely that bacteria in different stages of growth in the cultures used in the present experiments acted as separate compartments due to differences in enzyme content.

Another explanation for the present observations which must be considered is the possibility that the differences in the relative pool sizes observed in different incubation vessels during a single experiment were caused by variation in the immediate environment of the bacteria. Aeration is the only environmental factor which can reasonably be considered as a source of variation; it is difficult to appreciate how other local differences would have arisen. Temperature, mixing, population and medium were undoubtedly identical in each case. Each incubation vessel received a different labelled substrate, but these represented minute chemical quantities of material and we are unable to ascribe our results to differences resulting from unforeseen characteristics of the tracer preparations. Variations in the pool sizes of citric, glutamic and succinic acids have been observed as the result of the growth of Escherichia coli under anaerobic conditions. In such circumstances the tricarboxylic acid pathway acts not as a cycle but as two pathways branching at the point of entry of acetyl-CoA (Amarasingham \& Davis, 1965). However, the operation of the anaerobic mode of the tricarboxylic acid pathway requires that the formation of $\alpha$-ketoglutarate dehydrogenase be repressed (Amarasingham \& Davis, 1965) and a specific enzyme for the formation of succinate from fumarate (fumarate reductase) be induced (Hirsch, Raminsky, Davis \& Lin, 1963). The cultures in the incubation vessels in the present experiments were not growing because of the presence of chloramphenicol. Thus the presence or absence of any enzymes caused by anaerobiosis during the period of growth of the cultures would be observed in each of the incubation vessels to the same extent and so cannot be used to explain differences between them. Variations in the aeration of individual vessels might be expected to cause variations in the ratios of ATP/ADP, NADH/NAD ${ }^{+}$, etc., which would be reflected in the activities of a number of enzymes. However, the respiratory.studies reported above indicate that the bacteria in the labelling experiments were respiring at a constant and maximum rate, since the specific rate of respiration did not increase when the concentration of bacteria was decreased fourfold. In view of these results we do not consider that there were any differences between the degrees of aeration in different vessels during a single labelling experiment large enough to account for the considerably different metabolic patterns obtained.

The most probable explanation for the observations is that the products of metabolism of glucose and galactose, derived from either internal or external sources, feed into pools of citric, succinic and glutamic acid which are at least partially separate. It is, perhaps, surprising that the bacteria can maintain functional separation of the metabolic intermediates from different sources through so many enzymic stages, although the ability to do so is plainly an advantage from the point of view of metabolic control. This might be possible, however, if the enzymes on the pathways involved were very closely co-ordinated. The results presented above, particularly those in Fig. r, suggest that among the metabolic reactions we studied compartmentation plays a role only in distinguishing between hexoses produced within the bacteria and 
those presented to the exterior surface. Within each of these two categories the evidence suggests that glucose phosphate produced by epimerization of galactose phosphate equilibrates fully with glucose phosphate formed directly from free glucose. On the other hand, glucose phosphate derived from either of the hexoses in the medium is metabolically distinct from glucose phosphate derived from either of the hexoses produced by the hydrolysis of lactose.

Compartmentation of glycolytic metabolism in Escherichia coli has been suggested by Eisenberg \& Dobrogosz (1967) as a possible explanation for the fact that bacteria simultaneously oxidizing glucose and gluconate, oxidize the former exclusively by glycolysis and the latter exclusively by an inducible Entner-Doudoroff pathway. Pollock (1966) suggested that micro-organisms might co-ordinate their metabolic activity by incorporating enzymes into an organized structural framework. The growing amount of information on multi-enzyme complexes on the central pathways of metabolism tends to support the view that metabolic compartments do exist in bacteria. It has been known for some time from other systems that the enzymes responsible for the oxidative decarboxylation of pyruvate and $\alpha$-ketoglutarate exist in such particulate complexes (Reed \& Cox, 1966). There is also growing evidence for protein-protein interactions occurring much nearer the beginning of the glycolytic pathway. For instance, the activity of aldolase has been shown to be enhanced by glycerophosphate dehydrogenase (Baranowski \& Niederland, 1949) and by glyceraldehyde-3-phosphate dehydrogenase and triose phosphate isomerase (Gulyi, 1960; Gulyi, Dvornikova, Fedorchenko \& Pechenova, I962; Sereda, I963; Kwon \& Olcott, 1965). All these effects were ascribed to protein-protein interactions and not to effects due to the removal of end products. The effects were specific, and proteins not functionally related to the enzyme under study had no effect. These enzymes, which came from a variety of higher animal sources, are found in what is normally regarded as the soluble fraction of the cell, but this evidence suggests that there is in the living cell a high degree of cytoplasmic organization of enzymes functionally related to one another in metabolic sequences. If, in such complexes, an enzyme preferentially accepts its substrate from another enzyme in the complex, rather than from a 'soluble' pool, the situation would be one of compartmentation as described in the Introduction. The concept of metabolic compartmentation in bacteria has rarely been explicitly stated in the past but it is an important one with a significant bearing on the understanding of mechanisms of biological control.

D. McB. gratefully acknowledges the award of a NATO Fellowship from the British Government which enabled him to undertake this study. The work reported in this paper was sponsored by the U.S. Atomic Energy Commission.

\section{REFERENCES}

Abraham, S. \& Hassid, W. Z. (1957). The synthesis and degradation of isotopically labelled carbohydrates and carbohydrate derivatives. I. Synthesis of labelled carbohydrates. Meth. Enzymol. 4, 489.

AmARASINGHAM, C. R. \& Davis, B. D. (1965). Regulation of $\alpha$-ketoglutarate dehydrogenase formation in Escherichia coli. J. biol. Chem. 240, 3664.

BABAD, H. \& Hassid, W. Z. (1964). A soluble lactose-synthesizing enzyme from bovine milk. J. biol. Chem. 239, PC946.

Baranowski, T. \& Niederland, T. R. (1949). Aldolase activity of myogen A. J. biol. Chem. $180,543$. 
Bartley, J. C., Abraham, S. \& Chaikoff, I. L. (I966). Biosynthesis of lactose by mammary gland slices from the lactating rat. J. biol. Chem. 24I, I132.

Bean, R. C., Putman, E. W., Trucco, R. E. \& Hassid, W. Z. (1953). Preparation of C'14-labelled D-galactose and glycerol. J. biol. Chem. 204, I69.

EISENBERG, R. C. \& Dobrogosz, W. J. (1967). Gluconate metabolism in Escherichia coli. J. Bact. 93, 94I.

GULYI, M. F. (1960). Changes in the enzymic activity of proteins upon complex formation. HumboldtSymp. Grundfragen Biol. 3, 233. Berlin (publ. 1962).

Gulyi, M. F., Dvornikova, P. D., Fedorchenko, O. Y. \& Pechenova, T. M., (1962). Mechanism of enzyme activation of purified proteins. Ukr. biokhim. Zh. 34, 187.

Halvorson, H., Gorman, J., Tauro, P., Epstein, R. \& LaBerge, M. (1964). Control of enzyme synthesis in synchronous cultures of yeast. Fedn. Proc. Fedn. Am. Socs. exp. Biol. $23,1002$.

Hirsch, C. A., RAMinsKy, M., DaVIs, B. D. \& LiN, E. C. C. (I963). A fumarate reductase in Escherichia coli distinct from succinate dehydrogenase. J. biol. Chem. 238, 3770.

Kuempel, P. L., Masters, M. \& Pardee, A. B. (1965). Bursts of enzyme synthesis in the bacterial duplication cycle. Biochem. biophys. Res. Commun. 18, 858 .

Kwon, T. W. \& OlcotT, H. S. (1965). Augmentation of aldolase activity by glyceraldehyde-3-phosphate dehydrogenase. Biochem. biophys. Res. Commun. 19, 300.

LugG, J.W. H. \& Overell, B. T. (1948). One- and two-dimensional partition chromatographic separations of organic acids on an inert sheet support. Aust. J. scient. Res., Ser. A x, 98.

MASTERS, M. \& DONACHIE, W. D. (I966). Repression and the control of cyclic enzyme synthesis. Nature, Lond. 209, 476.

Masters, M., Kuempel, P. L. \& Pardee, A. B. (1964). Enzyme synthesis in synchronous cultures of bacteria. Biochem. biophys. Res. Commun. 15, 83.

McBrien, D. C. H. \& MoseS, V. (I966). The effect of isopropyl thiogalactoside on the induction of the galactose operon by D-fucose in a lactose-deletion mutant of Escherichia coli. J. Bact. 9r, I39I.

Moses, V. (1966). Aufgliederung des Stoffwechsels auf verschiedene Reaktionsräume. In Die Zelle: Struktur und Funktion. Ed. by H. Metzner, p. 248. Stuttgart: Wissenschaftliche Verlagsgesellschaft M.B.H.

Moses, V. \& LONBERG-Holm, K. K. (1963). A semi-automatic device for measuring radioactivity on two-dimensional paper chromatograms. Analyt. Biochem. 5, I I.

Moses, V. \& LONBERG-HoLM, K. K. (1966). The study of metabolic compartmentalization. J. theoret. Biol. ro, 336.

Pardee, A. B. \& Prestidge, L. S. (I96I). The initial kinetics of enzyme induction. Biochim. biophys. Acta 49, 77.

PoLLOCK, M. R. (1966). The co-ordination in space and time of metabolically coupled bacterial enzyme systems. Biochem. J. roo, $4 \mathrm{I}$ P.

Putman, E. W. \& Hassid, W. Z. (1952). Isolation and purification of radioactive sugars by means of paper chromatography. J. biol. Chem. 196, 749.

ReED, L. J. \& Cox, D. J. (I966). Macromolecular organization of enzyme systems. A. Rev. Biochem. $35,57$.

Schaechter, M., Williamson, J. P., Hood, Jun., J. R. \& Koch, A. L. (1962). Growth, cell and nuclear divisions in some bacteria. J. gen. Microbiol. 29, $42 \mathrm{I}$.

SEREDA, A. G. (1963). Effect of $\alpha$-glycerophosphate dehydrogenase on aldolase activity. Ukr. biokhim. Zh. 35, 410 .

Sмгтн, I. (1960). Sugars. In Chromatographic and Electrophoretic Techniques. Ed. by I. Smith, vol. I, Chromatography, p. 246, 2nd ed. London: Heinemann Medical Books. 